INDEPENDENT JOURNAL OF MANAGEMENT \& PRODUCTION (IJM\&P)

\title{
MANUFACTURING COST REDUCTIONS AND ECO EFFICIENCY : A RELATIONSHIP BASED ON A CASE STUDY
}

\author{
Rosangela Maria Vanalle \\ Universidade Nove de Julho - UNINOVE, Brazil \\ E-mail: rvanalle@uninove.br \\ Elpidio Moreira Costa \\ Universidade Nove de Julho - UNINOVE, Brazil \\ E-mail: elpidioconsultoria@gmail.com \\ Wagner Cezar Lucato \\ Universidade Nove de Julho - UNINOVE, Brazil \\ E-mail:wlucato@uninove.br \\ Submission: 01/04/2014 \\ Revision: 23/04/2014 \\ Accept: 07/05/2014
}

\section{ABSTRACT}

In the search for higher profits or competitiveness, firms have frequently used structured procedures to reduce their costs and expenses. However, the environmental consequences associated to those processes have hardly been considered. Hence, the central purpose of this paper is to show that it is possible to obtain relevant environmental gains even not considering the environmental issues as part of the operational cost reduction efforts. This particular point was verified through a single case study where value analysis was used to obtain manufacturing cost reductions in a company belonging to the Brazilian textile sector. Even not considering environmental aspects as part of the value analysis procedures, when the cost reduction actions were implemented it was possible to confirm that they also brought significant improvements to the environmental conditions, which were measured by the firm Eco efficiency levels before and after the cost reduction implementations.

Keywords: Value analysis; Eco efficiency; Textile industry. 


\section{INTRODUCTION}

In the globalized corporate environment many trends resulting from market or legal pressures end up being adopted by firms. Sustainability is one of these subjects, comprising its three pillar structure: economic efficiency, environmental protection and social justice (DESPEISSE et al., 2012; LUCATO et al., 2013a). Amaral (2002) defines sustainable development in line with the Brundtland report, i.e., it is the development that fulfills the present needs without compromising the ability of future generations to meet theirs. The sustainable development is a subject currently present in the manufacturing discussions. However it has not been widely explored by small companies in Brazil or worldwide (SILVA; MEDEIROS, 2004). Most of the researches are still focused in the large organizations, even though some initiatives can be found in the literature mostly considering pilot projects to enhance the entrepreneur conscience regarding the environmental issues (VERFAILLE; BIDWELL, 2000).

According to the World Business Council for Sustainable Development (WBCSD), the Eco efficiency means generating more value with less impact (VERFAILLE; BIDWELL, 2000). It aggregates the essential components to enhance the economic and environmental progress through a more efficient utilization of the production resources, generating at the same time lower emissions to the environment (SCHMIDHEINY, 2000).

In fact, based on the statements by Battaglia and Bergamo (2010) and Santana and Massarani (2005), firms have frequently employed cost reduction techniques like value analysis to pursue improvements in their manufacturing processes aiming at reducing their costs to increase their profits or their competitiveness. However, it has been observed in the literature that when such procedures are employed, very rarely the environmental aspects are taken into consideration.

Hence, the central objective of this paper is to demonstrate that in parallel to the cost reduction efforts, it is possible to obtain significant environmental gains to be measured through the firm Eco efficiency levels before and after the cost reduction actions. This was done through a single case study in which the value analysis was applied to the manufacturing process of a company belonging to the Brazilian textile 
DOI: 10.14807/ijmp.v5i4.219

sector. In such study, it was possible to verify that the original objective of the company management when applying the value analysis technique was solely to obtain manufacturing cost reductions. After the implementation of the value analysis actions required to lower the production costs it was possible to confirm that they also brought relevant contributions to the environment, as the firm Eco efficiency level increased meaningfully.

\section{LITERATURE REVIEW}

Value analysis is a methodology that guides the organization efforts to maximize its results using problem restructuring in the product design phase (SANTANA; MASSARANI, 2005). According to Santana and Massarani (2005), the product design should be defined based on the functions it should perform and not based on its components. To maximize the final result to be obtained by a given product, engineers should start from the function diagnosis and study alternative ways to perform them. This can be done through the resolution of a functional problem, the implementation of cost reductions or the improvement of the product performance.

To Cooper and Slagmulder (1997), the value engineering is a continuous study of the factors affecting the product cost, to find ways to reach the specified cost objective without sacrificing the quality and reliability standards. Its final goal is to reduce the manufacturing costs and related wastes through the implementation of project and process improvements (LESTER, 2013). Tanaka (1993) states that value engineering is not just an intellectual work that the designers and engineers usually perform in their labs and offices. It should be an effort aiming at improving the factory floor and production.

Conversely, for an organization to appraise its performance it is necessary the utilization of performance indicators that will be used to express the results of its different processes (ABNT, 2004). Verfaille and Bidwell (2000) indicate that the main objective of using environmental performance indicators is to contribute with the performance improvement of the organizations and monitor them with transparent, verifiable and relevant metrics for both the organization managers and also the remaining stakeholders. Verfaille and Bidwell (2000) state that the Eco efficiency can be measured by a relationship considering the two eco-dimensions: the economy 
DOI: 10.14807/ijmp.v5i4.219

and the ecology. This is accomplished as expressed in equation 1.

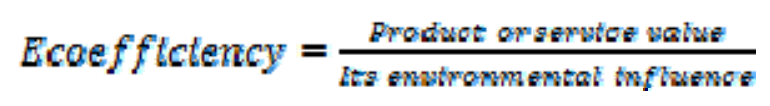

To adequately measure the Eco efficiency in a company following such general concept, Verfaille and Bidwell (2000) suggest the utilization of two kinds of indicators. The first is called the general type and is formed by indicators that can be used by almost all organizations. Besides being universally relevant, they refer to a global environmental concern, being their definitions generically established and accepted.

The indicators that do not fit into this category are named business specific. In this case, their utilization will depend on the specificities of one particular business or sector. These indicators are not less important than those of the first group even though they are less stringent in their utilization.

The Eco efficiency performance profile of a company should include both types of indicators and should be measured in two steps: i) an evaluation through time of the absolute values of the selected indicators to measure the product or service value and their respective environmental influence (comparing those values for two consecutive periods of time $n$ and $n+1$ ), and ii) the calculation and measurement through time of the Eco efficiency ratios (product or service value divided by its environmental influence). The progress of these two sets of indicators through time will enable the organization to have an adequate understanding of its Eco efficiency evolution (VERFAILLE; BIDWELL, 2000). To establish the general type indicators Verfaille and Bidwell (2000) suggest for the product or service value: i) the physical quantity of goods or services delivered to clients, and ii) net turnover. For the environmental influence they recommend: i) energy consumption, ii) material consumption, iii) water consumption, iv) green-house gas (GHG) emissions, and v) ozone depleting substances (ODS) emissions.

The literature that deals with Eco efficiency shows that its measurement has been done, almost exclusively, considering the environmental performance of a company considered as a whole (VERFAILLE; BIDWELL, 2000; SCHMIDHEINY, 2000; KOUSMANE; KORTELAINEN, 2005). However, it has not been located in the literature any theoretical or practical impossibility that would not allow the utilization 
DOI: 10.14807/ijmp.v5i4.219

of the same set of indicators to measure the Eco efficiency of a manufacturing process or even of a single piece of equipment. Nevertheless, there is a problem to do that.

As described earlier, the Eco efficiency progress measurement is done through the simultaneous monitoring of several individual indicators. Hence, there is a fair probability that different indicators move in opposite directions and, as a result, the traditional way of measuring the Eco efficiency could not tell if the Eco efficiency as a whole improved, worsened or remained constant. To overcome such difficulty, Lucato et al. (2013b) suggested that the Eco efficiency level of a manufacturing process $\mathrm{P}$, in a given moment $\mathrm{t}(\mathrm{EPt})$ could be calculated by the equation:

$$
E_{p t}=\sum_{i=1}^{n-1} \sum_{i=2}^{n} e_{i} \cdot e_{F n} \frac{\sin x}{2 n}, t<l
$$

where: e1, e2, e3,.., en are each one of the $n$ Eco efficiency indicators selected for the process $\mathrm{P}$ and $\alpha=360 \% / \mathrm{n}$. Using the equation 2 it was possible to determine the Eco efficiency level for the process chosen by this work.

\section{METHODS}

As mentioned before, the central objective of this paper is to generate theoretical knowledge and practical insights on how the firms could use the improvements in their manufacturing processes as a tool to also generate an increase in their Eco efficiency level. To reach that goal, the following research question was established: The implementation of actions aiming to reduce the manufacturing cost of companies through the utilization of the value analysis technique could also generate, in parallel, improvements in their Eco efficiency level?

To answer that question this paper investigated the value analysis practices and the Eco efficiency level in a dyeing and washing company belonging to the Brazilian textile sector. The case study method was selected because the research involved questions of the "how and/or why" type and also investigated an actual phenomenon in a real context where the borders between them were not clear Yin (2009).

To select the company considered in the case study, Patton (1990) recommends the utilization of purposeful sampling, i.e., cases from which the 
DOI: 10.14807/ijmp.v5i4.219

researcher could extract relevant information about the subjects that are significant for the research. Among the several strategies proposed by Patton (1990) to choose purposeful samples, this paper considered the typical case sampling in which the organization to be chosen should present a structured method to implement improvements in its manufacturing process.

In line with this assumption, two criteria were established to select the company to be considered in the case study: i) it should have recently implemented cost reduction projects using value analysis, and ii) it should grant the researchers full access to the data and information required to support this research. Following these criteria, it was chosen a small textile company located in the state of Parana in Brazil which dedicated to dyeing and washing jeans clothes. It is a small national family owned firm employing about 50 people and with a US\$3.5 million annual net turnover.

As a procedure to collect data in the elected company, it was decided to use the semi-structured interview because it is considered the best option when researching through a case study (Bryman, 1995; Collins and Hussey, 2003). Patton (1990) also endorses this recommendation recognizing that this data gathering technique should be employed whenever the researchers need flexibility to obtain information. To conduct the interviews and assure a uniform content in all them, an aide-memoire was prepared containing the relevant questions to be asked during the conversations with the interviewees.

As a result of the interviews, it was possible to note that the company under study did not take into account any environmental issues as part of its cost reduction efforts. To evaluate if those actions would also impact the manufacturing process environmental conditions, the researchers measured the Eco efficiency levels of the dyeing and washing area before and after the cost reduction implementation. To do that they initially defined the environmental performance indicators for the process area under evaluation, following the recommendations made by the WBCSD (VERFAILLE; BIDWELL, 2000).

As product or service value it was decided to use the monthly average net turnover and after a thorough evaluation of the dyeing and washing process the following indicators were selected to describe the environmental influence: electric 
DOI: 10.14807/ijmp.v5i4.219

energy consumption, the firewood consumption (used as heat source to power the boilers) and water consumption. As a result three Eco efficiency ratios were established following the WBCSD concept (product or service value / environmental influence), as shown in Figure 1.

Figure 1. The Eco efficiency indicators selected for the dyeing and washing process

\begin{tabular}{|c|c|c|c|}
\hline Indicators & $\begin{array}{c}\text { Product or service } \\
\text { value }\end{array}$ & Environmental Influence & $\begin{array}{l}\text { Eco efficiency } \\
\text { ratios }\end{array}$ \\
\hline $\mathrm{e}_{1}$ & $\begin{array}{c}\text { MNT } \\
\text { Monthly net turnover } \\
{[\text { US\$] }}\end{array}$ & $\begin{array}{c}\text { MEEC } \\
\text { Monthly electric energy } \\
\text { consumption [Kwh] }\end{array}$ & $\begin{array}{l}\text { MNT / MEEC } \\
\text { [US\$ / Kwh] }\end{array}$ \\
\hline $\mathrm{e}_{2}$ & $\begin{array}{c}\text { MNT } \\
\text { Monthly net turnover } \\
\text { [US\$] }\end{array}$ & $\begin{array}{c}\text { MFC } \\
\text { Monthly firewood } \\
\text { consumption }\left[10 \mathrm{~cm}^{3]}\right.\end{array}$ & $\begin{array}{c}\text { MNT / MFC } \\
\left.\text { [US\$ / } 10 \mathrm{~cm}^{3}\right]\end{array}$ \\
\hline$e_{3}$ & $\begin{array}{c}\text { MNT } \\
\text { Monthly net turnover } \\
\text { [US\$] }\end{array}$ & $\begin{array}{c}\text { MWC } \\
\text { Monthly water consumption } \\
{\left[10 \mathrm{~cm}^{3}\right]}\end{array}$ & $\begin{array}{l}\text { MNT / MWC } \\
{\left[U S \$ / 10 \mathrm{~cm}^{3}\right]}\end{array}$ \\
\hline
\end{tabular}

It should be mentioned that according to the recommendations made by Lucato et al. (2013b), the utilization of the equation 2 described earlier in this paper requires that the values assumed by the Eco efficiency ratios $\left(e_{1}, e_{2}\right.$ and $\left.e_{3}\right)$ should have the same orders of magnitude, reason why the units of measurement shown in Figure 1 were considered in this study. Once the Eco efficiency ratios were defined, the next step was to consider the selected ratios in the equation 2 to calculate the Eco efficiency level of the dyeing and washing process as follows:

$$
E_{F E}-\left[e_{1} \times e_{2}+e_{2} \times e_{5}+e_{1} \times e_{2}\right] \times \frac{\operatorname{sen} 12 \sigma^{\sigma x}}{2 \times 3}-0,1447 \times\left[e_{1} \times e_{2}+e_{2} \times e_{2}+e_{1} \times e_{2}\right]
$$

By using the equation 3 it was possible to calculate the Eco efficiency level of the process under evaluation before and after the cost reduction implementation.

\section{CASE STUDY}

As stated before, the case study was developed in two consecutive phases. Initially, the value analysis implemented by the firm under evaluation was deeply appraised by the researchers and the resulting economic gains were registered. Then, based on the information obtained, the researchers calculated the Eco efficiency level of the dyeing and washing process before and after the value analysis implementation. Results are reported as follows.

\subsection{The Financial Gains Resulting from the Value Analysis Implementation}


DOI: 10.14807/ijmp.v5i4.219

The value analysis implementation was performed by the company under study following the subsequent steps. As an initial stage, the objectives and goals for the cost reductions were established. As a performance indicator to gauge the reduction intents the some attributes of the manufacturing cost was defined. Also the implementation team was put together comprising one chemist and two manufacturing engineers. Finally an action plan was established considering the products and process to be evaluated.

As a second step, in the information phase, new options for raw material and process suppliers were searched. In parallel all the process sheets were revised and some typical product / process routings were selected to enable the determination of their respective manufacturing costs. Then the analysis phase began with the implementation team developing several meetings to collect process improvement ideas and possibilities of cost reductions as well as to evaluate eventual impacts on the organization resulting from the planned modifications. The time required to implement the changes was also assessed. As a result of this process, the implementation team proposed to replace the current type of chemical products, adopting in parallel a new dyeing and washing process to comply with that adjustment.

In the creativity phase the revised specifications were presented to several chemical product vendors, asking for their comments and suggestions to reduce costs and increase output. The best alternatives according to the value analysis team were tested in real life by means of pilot runs in which all the manufacturing organization took part and emitted their respective comments regarding each alternative tried. As a result, a new set of raw materials and a revised manufacturing process were selected by the implementation team as part of the judgment phase. Finally, in the implementation stage the selected raw materials were acquired in quantities required to support the production needs and the new process was put in place according to the plans established for that purpose.

Consequently, the aforesaid actions enabled the firm to accomplish significant cost reductions as shown in Table 1. The gains obtained as a result of the value analysis implementation took into account the monthly average consumption for each resource considering two comparable periods: the second half of 2011 (before the 
INDEPENDENT JOURNAL OF MANAGEMENT \& PRODUCTION (IJM\&P)

http://www.ijmp.jor.br

v. 5, n. 4, October - December 2014

ISSN: 2236-269X

DOI: 10.14807/ijmp.v5i4.219

implementation of the value analysis) and the second half of 2012 (after the implementation of the actions described above and allowing some time for the process to stabilize). However, it is important to point out that the volume of dyed and washed products in those two periods were significantly different as the average monthly net turnover increased more than $60 \%$ as shown in Table 1 (from US $\$ 211$ thousand in 2011 to US\$ 351 thousand in 2012). To consider the effects of such a growth on the gains obtained, it was calculated what the consumption of each resource would be in the second half of 2012, assuming that no improvement actions were implemented. Then, comparing the actual consumption of each item against those latest numbers it was possible to determine the actual amount of cost saved.

As can be seen, cost savings were significant: it was possible to obtain a $42.8 \%$ reduction in the raw material cost, $45.7 \%$ decrease in the electric energy cost, $43.9 \%$ cost improvement in the firewood cost and $10 \%$ savings in the cost of water consumption. In total it was possible to save almost $43 \%$ in the considered items of the manufacturing cost.

Table 1. Cost savings resulting from the value analysis implementation

\begin{tabular}{lrrrrr}
$\begin{array}{l}\text { (Average Monthly Values in } \\
\text { US\$) }\end{array}$ & $\begin{array}{r}\text { W/o Value } \\
\text { Analysis } \\
{[\mathrm{S} 2 \text { 2011] }}\end{array}$ & $\begin{array}{r}\text { W/o Value } \\
\text { Analysis } \\
{[\text { S2 2012] }}\end{array}$ & $\begin{array}{r}\text { With Value } \\
\text { Analysis } \\
{[\text { S2 2012] }}\end{array}$ & $\begin{array}{r}\text { Reduction } \\
{[\text { US } \$]}\end{array}$ & $\begin{array}{r}\text { Reduction } \\
{[\%]}\end{array}$ \\
\hline Net Turnover & 211,058 & 350,992 & 350,992 & & \\
\hline \multirow{2}{*}{ Raw Material Consumption } & 31,153 & 51,808 & 29,614 & 22,194 & 42.8 \\
& $14.8 \%$ & $14.8 \%$ & $8.4 \%$ & & \\
\hline \multirow{2}{*}{ Electric Energy Cost } & 12,883 & 21,425 & 11,637 & 9,788 & 45.7 \\
& $6.1 \%$ & $6.1 \%$ & $3.3 \%$ & & \\
\hline \multirow{2}{*}{ Firewood Consumption } & 13,221 & 21,987 & 12,327 & 9,660 & 43.9 \\
& $6.3 \%$ & $6.3 \%$ & $3.5 \%$ & & \\
\hline \multirow{2}{*}{ Water Consumption } & 1,644 & 2,734 & 2,471 & 263 & \\
& $0.8 \%$ & $0.8 \%$ & $0.7 \%$ & & \\
\hline \multirow{2}{*}{ Total } & $\mathbf{5 8 , 9 0 1}$ & $\mathbf{9 7 , 9 5 3}$ & $\mathbf{5 6 , 0 4 9}$ & $\mathbf{4 1 , 9 0 4}$ & $\mathbf{4 2 . 8}$ \\
& $\mathbf{2 7 . 9 \%}$ & $\mathbf{2 7 . 9 \%}$ & $\mathbf{1 6 . 0 \%}$ & & \\
\hline
\end{tabular}

\subsection{Environmental Impact Resulting from the Value Analysis Implementation}

As described earlier in this paper, the objective considered by the firm chosen to support the case study was to apply the value analysis technique to obtain cost 
DOI: 10.14807/ijmp.v5i4.219

reductions in its manufacturing process. Environmental concerns were never considered throughout the value analysis implementation process.

Nevertheless, to answer the central research question proposed by this work (can the value analysis technique also generate improvements in the Eco efficiency level?) the researchers obtained the required information that allowed them to calculate the Eco efficiency indicators as proposed in Figure 1.

For that purpose it were obtained the average monthly consumptions for electric energy (in Kwh), for firewood (in $10 \mathrm{~cm}^{3}$ ) and for water (also in $10 \mathrm{~cm}^{3}$ ), considering the two reference periods: second half of 2011 and second half of 2012. Those values were related to their respective average monthly net turnover to calculate the Eco efficiency indicators as proposed by this study. The results are presented in Table 2.

Table 2. Calculation of Eco efficiency indicators and respective process Eco efficiency levels

\begin{tabular}{|c|c|c|c|c|}
\hline (Average Monthly Values ) & & $\begin{array}{r}\text { W/o Value } \\
\text { Analysis } \\
\text { [S2 2011] }\end{array}$ & $\begin{array}{r}\text { With Value } \\
\text { Analysis } \\
\text { [S2 2012] }\end{array}$ & $\begin{array}{c}\text { Variation } \\
\%\end{array}$ \\
\hline Net Turnover (R\$) & & 211,058 & 350,992 & \\
\hline \multirow{2}{*}{ Electric Energy Consumption } & Kwh & 28,781 & 31.972 & \\
\hline & $\mathrm{e}_{1}[\mathrm{US} \$ / \mathrm{Kwh}]$ & 7.33 & 10.98 & 49.7 \\
\hline \multirow{2}{*}{ Firewood Consumption } & $10 \mathrm{~cm}^{3}$ & 25,400 & 23,700 & \\
\hline & $\mathrm{e}_{2}\left[\mathrm{US} / 10 \mathrm{~cm}^{3}\right]$ & 8.31 & 14.81 & 78.2 \\
\hline \multirow{2}{*}{ Water Consumption } & $10 \mathrm{~cm}^{3}$ & 34,500 & 51,900 & \\
\hline & $\mathrm{e}_{3}\left[\mathrm{US} 1 / 10 \mathrm{~cm}^{3}\right]$ & 6.12 & 6.76 & 10.5 \\
\hline Eco efficiency Level & $E_{M}$ & 22.66 & 48.76 & 115.1 \\
\hline
\end{tabular}

As can be seen, the indicators show an Eco efficiency increase of $49.7 \%$ for electric energy, $78.2 \%$ for firewood and $10.5 \%$ for water. Moreover, the utilization of the formula (2) above enabled the calculation of the Eco efficiency levels for the dyeing and washing process, before and after the value analysis implementation. It increased from 22.66 in 2011 to 48.76 in 2012, resulting in an improvement of more than $115 \%$ in the process Eco efficiency level. 
DOI: 10.14807/ijmp.v5i4.219

\section{CONCLUSIONS}

Sustainability has currently been a relevant theme in corporate discussions. However, it has not been considered in the vast majority of small companies, where short term survival ends up defining all the strategic and operational priorities. The case study presented by this paper confirmed this statement by showing the utilization of a structured tool to reduce manufacturing costs (value analysis) that did not consider the environmental impacts resulting from the actions taken.

Nonetheless, by measuring the Eco efficiency level of the manufacturing process under analysis it was possible to demonstrate that the activities defined to reduce costs also generated relevant environmental improvements, representing an important contribution to the sustainability level of the company and giving a favorable response to the proposed research question.

Hence, this paper brings some contributions to the body of knowledge of Production and Operations Management as it demonstrates that cost reduction processes can also bring environmental improvements, even if they have not been formally considered in the cost savings procedures. At the same time, the content presented here brings for the practitioners the idea that the environmental impacts of their manufacturing activities can be reduced without additional costs or investments.

On the contrary, as it was possible to verify in the case presented, the environmental improvement was obtained by simply measuring the respective Eco efficiency indicators and Eco efficiency levels before and after the cost reduction implementation. Usually, actions aimed at reducing the manufacturing costs can also favor an environmental gain.

Sure enough, this work has some limitations. First, as it involves a single case study, the conclusions obtained cannot be generalized. Also, the work developed herein considered only one kind of manufacturing process in the context of the textile industry. It is a fair supposition that the same results could not be obtained in different situations. As a result, to enlarge the possibilities of consideration of the results found by this paper, future research should be developed assuming a bigger number of firms, comprising different manufacturing processes belonging to different industrial sectors. 
INDEPENDENT JOURNAL OF MANAGEMENT \& PRODUCTION (IJM\&P) http://www.ijmp.jor.br

v. 5, n. 4, October - December 2014 ISSN: 2236-269X

DOI: 10.14807/ijmp.v5i4.219

\section{ACKNOWLEDGMENTS}

The authors are grateful to the Research Backing Fund of UNINOVE - Universidade Nove de Julho for the financial support to develop this work.

\section{REFERENCES}

ABNT - ASSOCIAÇÃO BRASILEIRA DE NORMAS TÉCNICAS. 2004. NBR ISO 14031: Gestão Ambiental - Avaliação de Desempenho Ambiental - diretrizes. ABNT, Rio de Janeiro.

AMARAL, S. P. (2002). Indicadores de sustentabilidade ambiental, social e econômica: uma proposta para a indústria de petróleo brasileira. In: VI Simpósio Ítalo Brasileiro de Engenharia Sanitária e Ambiental - SIBEASA, Vitoria, ES, Brazil.

BATTAGLIA, D.; BERGAMO, E. S. (2010). Análise de valor e engenharia de valor: uma ferramenta de redução de custos em um projeto. P\&D em Engenharia de Produção, v. 8, n. 3, p. 102-115.

BRYMAN, A. (1995). Research methods and organization studies. Routledge, London.

COLLINS,J.; HUSSEY, R. (2003). Business research methods. McGraw-Hill, New York, NY.

COOPER, R.; SLAGMULDER, R. (1997). Target costing and value engineering. Productivity, Portland.

DESPEISSE, M.; MBAYE, F.; BALL, P. D.; LEVERS, A. (2012). The emergence of sustainable manufacturing practices. Production Planning \& Control, v. 23, n. 5, p. 354-376.

KUOSMANE, T.; KORTELAINEN, M. (2005). Measuring ecoefficiency of production with data envelopment analysis. Journal of Industrial Ecology, v. 9, n. 4, p. 59-72.

LESTER, A. (2013). Project management, planning and control. 6th ed. Elsevier, Waltham.

LUCATO, W. C.; VANALLE, R. M.; SANTOS, J. C. S. (2013a). A practical evaluation of the industrial environmental practices and performance in the São Paulo metropolitan area. Espacios (Caracas), v. 34, n. 6, p. 3-13.

LUCATO, W. C.; VIEIRA JR., M.; SANTOS, J. C. S. (2013b). Measuring the ecoefficiency of a manufacturing process: a conceptual proposal. Management of Environmental Quality, v. 24, n. 6, p. 755-770.

PATTON, M. Q. (1990). Qualitative evaluation and research methods. Sage, Newbury Park.

SANTANA, A.; MASSARANI, M. (2005). Engenharia do valor associada ao

DFMEA no desenvolvimento do produto. SAE - Society of Automotive Engineers, São Paulo.

SCHMIDHEINY, S. (2000). Ecoefficiency - creating more value with less impact. WBCSD - World Business Council for Sustainable Development, Geneva. 
SILVA, G. C. S.; MEDEIROS, D. D. (2004). Environmental management in Brazilian companies. Management of Environmental Quality, v. 15, n. 4, p. 380-388.

TANAKA, T. (1993). Target costing at Toyota. Cost Management, v. 7, n. 1, p. 4-11. VERFAILLE, H. A.; BIDWELL, R. (2000). Measuring ecoefficiency - a guide to reporting company performance. WBCSD - World Business Council for Sustainable Development, Geneva.

YIN, R. K. (2009). Case study research: design and methods. 4th ed. Sage, Newbury Park. 